\title{
Recent progress in genetics of aging, senescence and longevity: focusing on cancer-related genes
}

\author{
Albert E. Berman ${ }^{1}$, Olga V. Leontieva², Venkatesh Natarajan'2, James A. McCubrey ${ }^{3}$, \\ Zoya N. Demidenko², Mikhail A. Nikiforov² \\ ${ }^{1}$ V.N. Orekhovich Institute of Biomedical Chemistry RAMS, 10 Pogodinskaya Str., Moscow, Russia \\ 2 Department Cell Stress Biology, Roswell Park Cancer Institute, Elm and Carlton Streets, Buffalo, NY \\ ${ }^{3}$ Department of Microbiology \& Immunology, Brody School of Medicine at East Carolina University, Greenville, NC \\ Correspondence to: Albert E. Berman, email: albertberman@rambler.ru
}

Keywords: senescence, quasi-programmed aging, diseases, cancer

Received: December 20,2012, Accepted: December 30, 2012, Published: December 30, 2012

Copyright: ( ) Berman et al. This is an open-access article distributed under the terms of the Creative Commons Attribution License, which permits unrestricted use, distribution, and reproduction in any medium, provided the original author and source are credited.

\section{ABSTRACT:}

It is widely believed that aging results from the accumulation of molecular damage, including damage of DNA and mitochondria and accumulation of molecular garbage both inside and outside of the cell. Recently, this paradigm is being replaced by the "hyperfunction theory", which postulates that aging is caused by activation of signal transduction pathways such as TOR (Target of Rapamycin). These pathways consist of different enzymes, mostly kinases, but also phosphatases, deacetylases, GTPases, and some other molecules that cause overactivation of normal cellular functions. Overactivation of these sensory signal transduction pathways can cause cellular senescence, age-related diseases, including cancer, and shorten life span. Here we review some of the numerous very recent publications on the role of signal transduction molecules in aging and age-related diseases. As was emphasized by the author of the "hyperfunction model", many (or actually all) of them also play roles in cancer. So these "participants" in pro-aging signaling pathways are actually very well acquainted to cancer researchers. A cancer-related journal such as Oncotarget is the perfect place for publication of such experimental studies, reviews and perspectives, as it can bridge the gap between cancer and aging researchers.

\section{Sirtuins}

Sirtuins are NAD+-dependent protein deacetylases, which regulate metabolism, stress responses, and aging processes. Mammalians possess seven Sirtuin isoforms, Sirt1-7, which differ in their subcellular localization and in the substrate proteins they deacetylate [1-6]. Sirtuins remain the most investigated proteins in the field of aging research. In the last several years numerous findings have extended our knowledge on their roles in aging and agerelated diseases and cancer [7-22].

Not only there are at least seven unique isoforms with different regulators and substrates, but they can exert opposite effects, including extension and shortening of life span, depending on the isoform, environmental conditions and animal species $[1,14,23-34]$. The biochemical functions of sirtuins are numerous $[26,35,36]$. As one of many examples, SIRT3-mediated deacetylation of cyclophilin D (CypD) on lysine 166 suppressed agerelated cardiac hypertrophy [37]. The class III histone deacetylase SIRT1 has been implicated in extension of lifespan. In the vasculature, SIRT1 was demonstrated to improve endothelial function. SIRT1 prevented endothelial superoxide production, inhibited NF-kappaB signaling, and diminished expression of adhesion molecules [38]. Treatment of hypercholesterolemic ApoE/- SIRT1+/- mice with lipopolysaccharide to boost NFkappaB signaling, led to a more pronounced endothelial expression of ICAM-1 and VCAM-1. Thus as emphasized by Stein et al, endogenous SIRT1 diminished endothelial activation in ApoE-/- mice [38]. The atheroprotective effects of SIRT1 observed in atherogenesis highlighted the need for additional translational research from bench-to-bedside on this topic [39]. Not coincidentally, modulators of sirtuins are considered as very promising 
targets for drug development [26, 40-44]. Virtual docking of a compound library into the peptide binding pockets of the crystal structures of Sirt2, 3, 5 and 6 yielded the compounds potentially discriminating between these isoforms. Further characterization in activity assays revealed two compounds with micromolar potency and high specificity for Sirt2 [4]. Sirtuins are also involved in cancer as one example of many age related diseases. For example, SIRT6 overexpression induced massive apoptosis in cancer but not normal cells [45].

\section{Target of rapamycin}

Sirtuins may exert different and sometimes opposite effects on longevity depending on the organism and environmental conditions. It was discussed recently that sirtuins could serve as modulators of the mTOR (mammalian target of rapamycin) pathway, by modulating and predominantly antagonizing mTOR activity, both upstream and downstream [46]. In 2009, Harrison, Miller and co-workers demonstrated that rapamycin, an inhibitor of mTOR, prolonged lifespan in mice [47]. This result was confirmed further by additional independent experiments and in different types (strains) of mice [48-56]. Furthermore, partial genetic inactivation of the mTOR pathway was known to prolong life span in different species from yeast to humans [57-61]. Based on the roles of mTOR in both cellular and organismal aging, as well as in age-related diseases, Mikhail Blagosklonny has predicted that rapamycin might extend lifespan, by slowing aging and delaying age-related diseases [62]. In 2003 , he proposed that active growth-promoting pathways that increase cellular size must in fact cause the senescent phenotype, when the cell cycle was blocked and actual cellular growth was not possible [63-64]. Inappropriate activation of some signaling pathways such as mTOR caused cellular hyperfunctions, and contributed to agerelated diseases [62]. The theory that aging is a quasiprogrammed aimless continuation of developmental growth [62, 65-72], was named the hyperfunction theory by Gems and coworkers, and was experimentally supported by studies in $C$ elegans $[73,74]$.

Recently, the role of mTOR in cellular senescence has been further investigated in a process named geroconversion $[75,76]$ and was further experimentally supported by studies at the cellular level [77-88]. Besides nutrients, mTOR is also activated by insulin, IGF-1, Ras, PI3K, Raf and other signal transduction molecules [89-93]. All of these signaling molecules are both proaging and oncoproteins, making mTOR a central player in both aging and cancer. Rapamycin and other rapalogs such as everolimus and temsirolimus and inhibitors of PI3K (upstream activator of TOR) are being prescribed or undergoing clinical trials for various cancer treatments [94-115].

\section{Insulin and IGF}

Reduced insulin and IGF-1 signaling has been associated with animal and human longevity [116-121]. On the other hand, inhibition of insulin/IGF-1 signaling is one anti-cancer strategy under intensive investigation [122-129].

\section{Ras and PI3K}

Ras and PI3K are potent inducers of cellular senescence, especially when cells cannot respond by increased proliferation [130-138]. Ras also participates in activities related to aging such as increased metabolism and autophagy [139]. The link between Ras and lifespan was further elucidated in a RasGrf1-deficient mouse model [140]. RasGRF1 is a Ras-guanine nucleotide exchange factor implicated in a variety of physiological processes. In aged RasGrf1(-/-) mice, increases in average and maximal lifespan, were associated with lower IGF-I levels and increased SIRT1 levels. Life extension was not due to the role of Ras in cancer or a protection against oxidative stress. In addition, cardiac glucose consumption was changed by aging in the mutant mouse model, indicating that RasGrf1-deficient mice displayed elevated aging [140-142]. Additional work supporting the role of Ras in organismal aging, demonstrated that Ras can accelerate aging [118, 143, 144], consistent with 'the hyperfunctional model' of aging driven by growth-promoting activators of the mTOR global network. Needless to say, Ras, Raf, PI3K and Akt are some of most important players in cancer and therefore targets for therapy. Recently clear progress in therapeutic applications of inhibiting these targets has been demonstrated [98, 104, 107,112, [144-155]

p53

The p53 tumor suppressor is one of the most famous inducers of cellular senescence [134, 137, 156161]. Moreover, this outcome was demonstrated to be ensured when p53 caused cell cycle arrest but failed to inhibit the mTOR pathway [162]. By inhibiting mTOR [163], p53 can suppress the senescence program, the senescent phenotype and associated morphology, resulting in reversible arrest [164]. Since p53 can inhibit mTOR under certain conditions in various cells, it may cause quiescence instead of senescence [165-171]. p53 was demonstrated to inhibit geroconversion (a conversion from quiescence or simple arrest to senescence [76]) and, importantly, it did not cause senescence in quiescent cells [79]. Not surprisingly, the effects of p53 on longevity may vary $[33,172-180]$. On the other hand, since p53 is the most frequently mutated tumor suppressor gene, p53 is under further investigations for various cancer therapies 
to characterize and develop new drugs and approaches for targeting both mutated and WT p53 [181-194].

HIF-1 is often induced in cancer in response to hypoxic conditions, which by the way inhibit senescence in a HIF-1-independent fashion. Interestingly, HIF-1alpha protects against drug-induced apoptosis by antagonizing the functions of p53 [195]. HIF-1alpha upregulation induced proteasomal degradation of homeodomaininteracting protein kinase-2 (HIPK2), a p53 apoptotic activator [195]. Agents that target HIF-1 are under further development [196-202].

Another strategy is induction of $\mathrm{p} 53$ for protection of normal cells from cycle-dependent chemotherapy, currently known as chemo-cyclo-therapy or cyclo-therapy [203-209].

\section{p63 and p73}

p63 and p73, relatives of p53, play even more diverse role in aging [210-215]. One unusual pro-aging role of p73 has been recently demonstrated. Female reproductive aging is often associated with increases in egg aneuploidy [216]. It was observed that TAp73 isoforms were down regulated in oocytes from women older than 38 years. TAp73 down regulation in oocytes from women of advanced reproductive age could explain both the reduction of fertility and the increase in frequency of newborns with chromosomal abnormalities [216]. p63 and p73 are also important targets for anti-cancer therapies [204, 217-230].

\section{REFERENCE}

1. Finkel T, Deng CX, Mostoslavsky R. Recent progress in the biology and physiology of sirtuins. Nature. 2009; 460: 587-591.

2. Guarente L. Sirtuins in aging and disease. Cold Spring Harb Symp Quant Biol. 2007; 72: 483-488.

3. Timmer S, Auwerx J, Schrauwen P. The journey of resveratrol from yeast to human. Aging (Albany NY). 2012; 4: $146-158$.

4. Schlicker C, Boanca G, Lakshminarasimhan M, Steegborn C. Structure-based development of novel sirtuin inhibitors. Aging (Albany NY). 2011; 3: 852-872.

5. Westphal CH, Dipp MA, Guarente L. A therapeutic role for sirtuins in diseases of aging? Trends Biochem Sci. 2007; 555-60: 555-560.

6. Vijg J, Maslov AY, Suh Y. Aging: a sirtuin shake-up? Cell. 2008; 135: 797-798.

7. Calvanese V, Fraga MF. SirT1 brings stemness closer to cancer and aging. Aging (Albany NY). 2011; 3: 162-167.

8. Canto C, Auwerx J. Interference between PARPs and SIRT1: a novel approach to healthy ageing? Aging (Albany NY). 2011; 3: 543-547.
9. Choudhury M, Jonscher KR, Friedman JE. Reduced mitochondrial function in obesity-associated fatty liver: SIRT3 takes on the fat. Aging (Albany NY). 2011; 3: 175178.

10. Ha CW, Huh WK. The implication of Sir2 in replicative aging and senescence in Saccharomyces cerevisiae. Aging (Albany NY). 2011; 3: 319-324.

11. Herranz D, Serrano M. Impact of Sirt1 on mammalian aging. Aging (Albany NY). 2010; 2: 315-316.

12. Yu J, Auwerx J. The role of sirtuins in the control of metabolic homeostasis. Ann N Y Acad Sci. 2009; 1173 Suppl 1: E10-19.

13. Couzin-Frankel J. Genetics. Aging genes: the sirtuin story unravels. Science. 2011; 334: 1194-1198.

14. Lee J, Kemper JK. Controlling SIRT1 expression by microRNAs in health and metabolic disease. Aging (Albany NY). 2010; 2: 527-534.

15. Liu Y, Zhang D, Chen D. SIRT3: Striking at the heart of aging. Aging (Albany NY). 2011; 3: 1-2.

16. Liao CY, Kennedy BK. Will the real aging Sirtuin please stand up? Cell Res. 2012; 22: 1215-1217.

17. Pardo PS, Boriek AM. The physiological roles of Sirt1 in skeletal muscle. Aging (Albany NY). 2011; 3: 430-437.

18. Vetterli L, Maechler P. Resveratrol-activated SIRT1 in liver and pancreatic beta-cells: a Janus head looking to the same direction of metabolic homeostasis. Aging (Albany NY). 2011; 3: 444-449.

19. Houtkooper RH, Pirinen E, Auwerx J. Sirtuins as regulators of metabolism and healthspan. Nat Rev Mol Cell Biol. 2012; 13: 225-238.

20. Bai P, Canto C, Oudart H, Brunyanszki A, Cen Y, Thomas C, Yamamoto H, Huber A, Kiss B, Houtkooper RH, Schoonjans K, Schreiber V, Sauve AA, Menissierde Murcia J, Auwerx J. PARP-1 inhibition increases mitochondrial metabolism through SIRT1 activation. Cell Metab. 2011; 13: 461-468.

21. Zhang D, Liu Y, Chen D. SIRT-ain relief from age-inducing stress. Aging (Albany NY). 2011; 3: 158-161.

22. Liu Z, Sun LY. Complex roles of Sirtuin 1 in cancer and aging. Transl Res. 2011; 157: 273-275.

23. Nogueiras R, Habegger KM, Chaudhary N, Finan B, Banks AS, Dietrich MO, Horvath TL, Sinclair DA, Pfluger PT, Tschop MH. Sirtuin 1 and sirtuin 3: physiological modulators of metabolism. Physiol Rev. 2012; 92: 14791514.

24. Saunders LR, Sharma AD, Tawney J, Nakagawa M, Okita K, Yamanaka S, Willenbring H, Verdin E. miRNAs regulate SIRT1 expression during mouse embryonic stem cell differentiation and in adult mouse tissues. Aging (Albany NY). 2010; 2: 415-431.

25. Ramadori G, Fujikawa T, Anderson J, Berglund ED, Frazao R, Michan S, Vianna CR, Sinclair DA, Elias CF, Coppari R. SIRT1 deacetylase in SF1 neurons protects against metabolic imbalance. Cell Metab. 2011; 14: 301-312. 
26. Price NL, Gomes AP, Ling AJ, Duarte FV, MartinMontalvo A, North BJ, Agarwal B, Ye L, Ramadori G, Teodoro JS, Hubbard BP, Varela AT, Davis JG, Varamini $\mathrm{B}$, Hafner A, Moaddel R et al. SIRT1 is required for AMPK activation and the beneficial effects of resveratrol on mitochondrial function. Cell Metab. 2012; 15: 675-690.

27. Hirschey MD, Shimazu T, Capra JA, Pollard KS, Verdin E. SIRT1 and SIRT3 deacetylate homologous substrates: AceCS1,2 and HMGCS1,2. Aging (Albany NY). 2011; 3: 635-642.

28. Ramadori G, Coppari R. Does hypothalamic SIRT1 regulate aging? Aging (Albany NY). 2011; 3: 325-328

29. Pearson KJ, Baur JA, Lewis KN, Peshkin L, Price NL, Labinskyy N, Swindell WR, Kamara D, Minor RK, Perez E, Jamieson HA, Zhang Y, Dunn SR, Sharma K, Pleshko $\mathrm{N}$, Woollett LA et al. Resveratrol delays age-related deterioration and mimics transcriptional aspects of dietary restriction without extending life span. Cell Metab. 2008; 8: $157-168$.

30. Sadoshima J. Sirt3 targets $\mathrm{mPTP}$ and prevents aging in the heart. Aging (Albany NY). 2011; 3: 12-13.

31. Van Meter M, Mao Z, Gorbunova V, Seluanov A. Repairing split ends: SIRT6, mono-ADP ribosylation and DNA repair. Aging (Albany NY). 2011; 3: 829-835.

32. Vendrell A, Posas F. Sir2 plays a key role in cell fate determination upon SAPK activation. Aging (Albany NY). 2011; 3: 1163-1168.

33. Antosh M, Whitaker R, Kroll A, Hosier S, Chang C, Bauer J, Cooper L, Neretti N, Helfand SL. Comparative transcriptional pathway bioinformatic analysis of dietary restriction, Sir2, p53 and resveratrol life span extension in Drosophila. Cell Cycle. 2011; 10: 904-911.

34. Herranz D, Iglesias G, Munoz-Martin M, Serrano M. Limited role of Sirt1 in cancer protection by dietary restriction. Cell Cycle. 2011; 10: 2215-2217.

35. Fatoba ST, Okorokov AL. Human SIRT1 associates with mitotic chromatin and contributes to chromosomal condensation. Cell Cycle. 2011; 10: 2317-2322.

36. Milner J, Allison SJ. SIRT1, p53 and mitotic chromosomes. Cell Cycle. 2011;10: 3049.

37. Hafner AV, Dai J, Gomes AP, Xiao CY, Palmeira CM, Rosenzweig A, Sinclair DA. Regulation of the mPTP by SIRT3-mediated deacetylation of CypD at lysine 166 suppresses age-related cardiac hypertrophy. Aging (Albany NY). 2010; 2: 914-923.

38. Stein S, Schafer N, Breitenstein A, Besler C, Winnik S, Lohmann C, Heinrich K, Brokopp CE, Handschin C, Landmesser U, Tanner FC, Luscher TF, Matter CM. SIRT1 reduces endothelial activation without affecting vascular function in ApoE-/- mice. Aging (Albany NY). 2010; 2: 353-360.

39. Stein S, Matter CM. Protective roles of SIRT1 in atherosclerosis. Cell Cycle. 2011; 10: 640-647.

40. Morselli E, Shen S, Ruckenstuhl C, Bauer MA, Marino G,
Galluzzi L, Criollo A, Michaud M, Maiuri MC, Chano T, Madeo F, Kroemer G. p53 inhibits autophagy by interacting with the human ortholog of yeast Atg17, RB1CC1/FIP200. Cell Cycle. 2011; 10: 2763-2769.

41. Howitz KT, Bitterman KJ, Cohen HY, Lamming DW, Lavu S, Wood JG, Zipkin RE, Chung P, Kisielewski A, Zhang LL, Scherer B, Sinclair DA. Small molecule activators of sirtuins extend Saccharomyces cerevisiae lifespan. Nature. 2003; 425: 191-196.

42. Baur JA, Chen D, Chini EN, Chua K, Cohen HY, de Cabo R, Deng C, Dimmeler S, Gius D, Guarente LP, Helfand SL, Imai S, Itoh H, Kadowaki T, Koya D, Leeuwenburgh C et al. Dietary restriction: standing up for sirtuins. Science. 2010; 329: 1012-1013; author reply 1013-1014.

43. Medvedik O, Lamming DW, Kim KD, Sinclair DA. MSN2 and MSN4 Link Calorie Restriction and TOR to SirtuinMediated Lifespan Extension in Saccharomyces cerevisiae. PLoS Biol. 2007; 5: e261.

44. Morselli E, Galluzzi L, Kepp O, Criollo A, Maiuri MC, Tavernarakis N, Madeo F, Kroemer G. Autophagy mediates pharmacological lifespan extension by spermidine and resveratrol. Aging (Albany NY). 2009; 1: 961-970.

45. Van Meter M, Mao Z, Gorbunova V, Seluanov A. SIRT6 overexpression induces massive apoptosis in cancer cells but not in normal cells. Cell Cycle. 2011; 10: 3153-3158.

46. Blagosklonny MV. Linking calorie restriction to longevity through sirtuins and autophagy: any role for TOR. Cell Death Dis 1:e12;doi:101038/cddis200917. 2010.

47. Harrison DE, Strong R, Sharp ZD, Nelson JF, Astle CM, Flurkey K, Nadon NL, Wilkinson JE, Frenkel K, Carter CS, Pahor M, Javors MA, Fernandezr E, Miller RA. Rapamycin fed late in life extends lifespan in genetically heterogenous mice. Nature. 2009; 460: 392-396.

48. Miller RA, Harrison DE, Astle CM, Baur JA, Boyd AR, de Cabo R, Fernandez E, Flurkey K, Javors MA, Nelson JF, Orihuela CJ, Pletcher S, Sharp ZD, Sinclair D, Starnes JW, Wilkinson JE et al. Rapamycin, but not resveratrol or simvastatin, extends life span of genetically heterogeneous mice. J Gerontol A Biol Sci Med Sci. 2011; 66: 191-201.

49. Anisimov VN, Zabezhinski MA, Popovich IG, Piskunova TS, Semenchenko AV, Tyndyk ML, Yurova MN, Antoch MP, Blagosklonny MV. Rapamycin extends maximal lifespan in cancer-prone mice. Am J Pathol. 2010; 176: 2092-2097.

50. Anisimov VN, Zabezhinski MA, Popovich IG, Piskunova TS, Semenchenko AV, Tyndyk ML, Yurova MN, Rosenfeld SV, Blagosklonny MV. Rapamycin increases lifespan and inhibits spontaneous tumorigenesis in inbred female mice. Cell Cycle. 2011; 10: 4230-4236.

51. Majumder S, Caccamo A, Medina DX, Benavides AD, Javors MA, Kraig E, Strong R, Richardson A, Oddo $\mathrm{S}$. Lifelong rapamycin administration ameliorates agedependent cognitive deficits by reducing IL-1beta and enhancing NMDA signaling. Aging Cell. 2012; 11: 326- 
335.

52. Spong A, Bartke A. Rapamycin slows aging in mice. Cell Cycle. 2012; 11:845.

53. Selman C, Partridge L. A double whammy for aging? Rapamycin extends lifespan and inhibits cancer in inbred female mice. Cell Cycle. 2012; 11: 17-18.

54. Wilkinson JE, Burmeister L, Brooks SV, Chan CC, Friedline S, Harrison DE, Hejtmancik JF, Nadon N, Strong R, Wood LK, Woodward MA, Miller RA. Rapamycin slows aging in mice. Aging Cell. 2012; 11: 675-682.

55. Comas M, Toshkov I, Kuropatwinski KK, Chernova OB, Polinsky A, Blagosklonny MV, Gudkov AV, Antoch MP. New nanoformulation of rapamycin Rapatar extends lifespan in homozygous p53-/- mice by delaying carcinogenesis. Aging (Albany NY). 2012; 4: 715-722.

56. Komarova EA, Antoch MP, Novototskaya LR, Chernova OB, Paszkiewicz G, Leontieva OV, Blagosklonny MV, Gudkov AV. Rapamycin extends lifespan and delays tumorigenesis in heterozygous p53+/- mice. Aging (Albany NY). 2012; 4: 709-714.

57. Kaeberlein M, Kennedy BK. Ageing: A midlife longevity drug? Nature. 2009; 460: 331-332.

58. Selman C, Tullet JM, Wieser D, Irvine E, Lingard SJ, Choudhury AI, Claret M, Al-Qassab H, Carmignac D, Ramadani F, Woods A, Robinson IC, Schuster E, Batterham RL, Kozma SC, Thomas G et al. Ribosomal protein S6 kinase 1 signaling regulates mammalian life span. Science. 2009; 326: 140-144.

59. Kapahi P, Chen D, Rogers AN, Katewa SD, Li PW, Thomas EL, Kockel L. With TOR, less is more: a key role for the conserved nutrient-sensing TOR pathway in aging. Cell Metab. 2010; 11: 453-465.

60. Kapahi P, Zid BM, Harper T, Koslover D, Sapin V, Benzer $\mathrm{S}$. Regulation of lifespan in Drosophila by modulation of genes in the TOR signaling pathway. Curr Biol. 2004; 14: 885-890.

61. Katewa SD, Kapahi P. Role of TOR signaling in aging and related biological processes in Drosophila melanogaster. Exp Gerontol. 2011; 46: 382-390.

62. Blagosklonny MV. Aging and immortality: quasiprogrammed senescence and its pharmacologic inhibition. Cell Cycle. 2006; 5: 2087-2102.

63. Blagosklonny MV. Cell senescence and hypermitogenic arrest. EMBO Rep. 2003; 4: 358-362.

64. Demidenko ZN, Blagosklonny MV. Growth stimulation leads to cellular senescence when the cell cycle is blocked. Cell Cycle. 2008; 7: 3355-3361.

65. Blagosklonny MV, Hall MN. Growth and aging: a common molecular mechanism. Aging. 2009; 1: 357-362.

66. Blagosklonny MV. Increasing healthy lifespan by suppressing aging in our lifetime: Preliminary proposal. Cell Cycle. 2010; 9: 4788-4794.

67. Blagosklonny MV. Calorie restriction: Decelerating mTORdriven aging from cells to organisms (including humans).
Cell Cycle. 2010; 9: 683-688.

68. Blagosklonny MV. Rapamycin and quasi-programmed aging: Four years later. Cell Cycle. 2010; 9: 1859-1862.

69. Blagosklonny MV. Prospective treatment of age-related diseases by slowing down aging. Am J Pathol. 2012; 181: 1142-1146.

70. Blagosklonny MV. Revisiting the antagonistic pleiotropy theory of aging: TOR-driven program and quasi-program. Cell Cycle. 2010; 9: 3151-3156.

71. Blagosklonny MV. Why the disposable soma theory cannot explain why women live longer and why we age. Aging (Albany NY). 2010; 2: 884-887.

72. Blagosklonny MV. Hormesis does not make sense except in the light of TOR-driven aging. Aging (Albany NY). 2011; 3: 1051-1062.

73. Gems D, Partridge L. Genetics of Longevity in Model Organisms: Debates and Paradigm Shifts. Annu Rev Physiol. Epub 2012 Nov 26.

74. Gems DH, de la Guardia YI. Alternative Perspectives on Aging in C. elegans: Reactive Oxygen Species or Hyperfunction? Antioxid Redox Signal. 2012.

75. Blagosklonny MV. Cell cycle arrest is not senescence. Aging (Albany NY). 2011; 3: 94-101.

76. Blagosklonny MV. Cell cycle arrest is not yet senescence, which is not just cell cycle arrest: terminology for TORdriven aging. Aging (Albany NY). 2012; 4: 159-165.

77. Zhuang D, Mannava S, Grachtchouk V, Tang WH, Patil S, Wawrzyniak JA, Berman AE, Giordano TJ, Prochownik EV, Soengas MS, Nikiforov MA. C-MYC overexpression is required for continuous suppression of oncogene-induced senescence in melanoma cells. Oncogene. 2008; 27 : 66236634.

78. Demidenko ZN, Zubova SG, Bukreeva EI, Pospelov VA, Pospelova TV, Blagosklonny MV. Rapamycin decelerates cellular senescence. Cell Cycle. 2009; 8: 1888-1895.

79. Leontieva OV, Blagosklonny MV. DNA damaging agents and p53 do not cause senescence in quiescent cells, while consecutive re-activation of mTOR is associated with conversion to senescence. Aging (Albany NY). 2010; 2: 924-935.

80. Romanov VS, Abramova MV, Svetlikova SB, Bykova TV, Zubova SG, Aksenov ND, Fornace AJ, Jr., Pospelova TV, Pospelov VA. p21(Waf1) is required for cellular senescence but not for cell cycle arrest induced by the HDAC inhibitor sodium butyrate. Cell Cycle. 2010; 9: 3945-3955.

81. Leontieva OV, Natarajan V, Demidenko ZN, Burdelya LG, Gudkov AV, Blagosklonny MV. Hypoxia suppresses conversion from proliferative arrest to cellular senescence. Proc Natl Acad Sci U S A. 2012; 109: 13314-13318.

82. Pospelova TV, Leontieva OV, Bykova TV, Zubova SG, Pospelov VA, Blagosklonny MV. Suppression of replicative senescence by rapamycin in rodent embryonic cells. Cell Cycle. 2012; 11: 2402-2407.

83. Narita M, Young AR, Arakawa S, Samarajiwa SA, 
Nakashima T, Yoshida S, Hong S, Berry LS, Reichelt S, Ferreira M, Tavare S, Inoki K, Shimizu S. Spatial coupling of mTOR and autophagy augments secretory phenotypes. Science. 2011; 332: 966-970.

84. Menendez JA, Vellon L, Oliveras-Ferraros C, Cufi S, Vazquez-Martin A. mTOR-regulated senescence and autophagy during reprogramming of somatic cells to pluripotency: a roadmap from energy metabolism to stem cell renewal and aging. Cell Cycle. 2011; 10: 3658-3677.

85. Kolesnichenko M, Hong L, Liao R, Vogt PK, Sun P. Attenuation of TORC1 signaling delays replicative and oncogenic RAS-induced senescence. Cell Cycle. 2012; 11: 2391-2401.

86. Cao K, Graziotto JJ, Blair CD, Mazzulli JR, Erdos MR, Krainc D, Collins FS. Rapamycin reverses cellular phenotypes and enhances mutant protein clearance in Hutchinson-Gilford progeria syndrome cells. Sci Transl Med. 2011; 3: 89ra58.

87. Cho S, Hwang ES. Status of mTOR activity may phenotypically differentiate senescence and quiescence. Mol Cells. 2012; 33: 597-604.

88. Pani G. From growing to secreting: new roles for $\mathrm{mTOR}$ in aging cells. Cell Cycle. 2011; 10: 2450-2453.

89. Schmelzle T, Hall MN. TOR, a central controller of cell growth. Cell. 2000; 103: 253-262.

90. Laplante M, Sabatini DM. mTOR signaling in growth control and disease. Cell. 2012; 149: 274-293.

91. Wullschleger S, Loewith R, Hall MN. TOR signaling in growth and metabolism. Cell. 2006; 124: 471-484.

92. Zoncu R, Efeyan A, Sabatini DM. mTOR: from growth signal integration to cancer, diabetes and ageing. Nat Rev Mol Cell Biol. 2011; 12: 21-35.

93. Sengupta S, Peterson TR, Sabatini DM. Regulation of the mTOR complex 1 pathway by nutrients, growth factors, and stress. Mol Cell. 2010; 40: 310-322.

94. Motzer RJ, Hudes GR, Curti BD, McDermott DF, Escudier BJ, Negrier S, Duclos B, Moore L, O’Toole T, Boni JP, Dutcher JP. Phase I/II trial of temsirolimus combined with interferon alfa for advanced renal cell carcinoma. J Clin Oncol. 2007; 25: 3958-3964.

95. Hudes G, Carducci M, Tomczak P, Dutcher J, Figlin R, Kapoor A, Staroslawska E, Sosman J, McDermott D, Bodrogi I, Kovacevic Z, Lesovoy V, Schmidt-Wolf IG, Barbarash O, Gokmen E, O'Toole T et al. Temsirolimus, interferon alfa, or both for advanced renal-cell carcinoma. N Engl J Med. 2007; 356: 2271-2281.

96. Boehrer S, Galluzzi L, Lainey E, Bouteloup C, Tailler M, Harper F, Pierron G, Ades L, Thepot S, Sebert M, Gardin C, de Botton S, Fenaux P, Kroemer G. Erlotinib antagonizes constitutive activation of SRC family kinases and mTOR in acute myeloid leukemia. Cell Cycle. 2011; 10: 3168-3175.

97. Gruppuso PA, Boylan JM, Sanders JA. The physiology and pathophysiology of rapamycin resistance: implications for cancer. Cell Cycle. 2011; 10: 1050-1058.
98. Meric-Bernstam F, Akcakanat A, Chen H, Do KA, Sangai T, Adkins F, Gonzalez-Angulo AM, Rashid A, Crosby K, Dong M, Phan AT, Wolff RA, Gupta S, Mills GB, Yao J. PIK3CA/PTEN mutations and Akt activation as markers of sensitivity to allosteric mTOR inhibitors. Clin Cancer Res. 2012; 18: 1777-1789.

99. Bracarda S, Hutson TE, Porta C, Figlin RA, Calvo E, Grunwald V, Ravaud A, Motzer R, Kim D, Anak O, Panneerselvam A, Escudier B. Everolimus in metastatic renal cell carcinoma patients intolerant to previous VEGFrTKI therapy: a RECORD-1 subgroup analysis. Br J Cancer. 2012; 106: 1475-1480.

100. Bhaskar PT, Hay N. The Two TORCs and Akt. Dev Cell. 2007; 12: 487-502.

101. Chollet P, Abrial C, Tacca O, Mouret-Reynier MA, Leheurteur M, Durando X, Cure H. Mammalian target of rapamycin inhibitors in combination with letrozole in breast cancer. Clin Breast Cancer. 2006; 7: 336-338.

102. Yellen P, Saqcena M, Salloum D, Feng J, Preda A, Xu L, Rodrik-Outmezguine V, Foster DA. High-dose rapamycin induces apoptosis in human cancer cells by dissociating mTOR complex 1 and suppressing phosphorylation of 4EBP1. Cell Cycle. 2011; 10: 3948-3956.

103. Iyer G, Hanrahan AJ, Milowsky MI, Al-Ahmadie H, Scott SN, Janakiraman M, Pirun M, Sander C, Socci ND, Ostrovnaya I, Viale A, Heguy A, Peng L, Chan TA, Bochner B, Bajorin DF et al. Genome sequencing identifies a basis for everolimus sensitivity. Science. 2012; 338: 221.

104. Martelli AM, Chiarini F, Evangelisti C, Cappellini A, Buontempo F, Bressanin D, Fini M, McCubrey JA. Two hits are better than one: targeting both phosphatidylinositol 3-kinase and mammalian target of rapamycin as a therapeutic strategy for acute leukemia treatment. Oncotarget. 2012; 3: 371-394.

105. Mercier I, Camacho J, Titchen K, Gonzales DM, Quann $\mathrm{K}$, Bryant KG, Molchansky A, Milliman JN, WhitakerMenezes D, Sotgia F, Jasmin JF, Schwarting R, Pestell RG, Blagosklonny MV, Lisanti MP. Caveolin-1 and accelerated host aging in the breast tumor microenvironment: chemoprevention with rapamycin, an mTOR inhibitor and anti-aging drug. Am J Pathol. 2012; 181: 278-293.

106. Ho AL, Vasudeva SD, Lae M, Saito T, Barbashina V, Antonescu CR, Ladanyi M, Schwartz GK. PDGF receptor alpha is an alternative mediator of rapamycin-induced Akt activation: implications for combination targeted therapy of synovial sarcoma. Cancer Res. 2012; 72: 4515-4525.

107. Garrett JT, Chakrabarty A, Arteaga CL. Will PI3K pathway inhibitors be effective as single agents in patients with cancer? Oncotarget. 2011; 2: 1314-1321.

108. Floc'h N, Kinkade CW, Kobayashi T, Aytes A, Lefebvre C, Mitrofanova A, Cardiff RD, Califano A, Shen MM, AbateShen C. Dual targeting of the Akt/mTOR signaling pathway inhibits castration-resistant prostate cancer in a genetically engineered mouse model. Cancer Res. 2012; 72: 44834493. 
109. Khanna A, Kapahi P. Rapamycin: killing two birds with one stone. Aging (Albany NY). 2011; 3: 1043-1044.

110. Euvrard S, Morelon E, Rostaing L, Goffin E, Brocard A, Tromme I, Broeders N, del Marmol V, Chatelet V, Dompmartin A, Kessler M, Serra AL, Hofbauer GF, Pouteil-Noble C, Campistol JM, Kanitakis J et al. Sirolimus and secondary skin-cancer prevention in kidney transplantation. N Engl J Med. 2012; 367: 329-339.

111. Wang Y, Wang XY, Subjeck JR, Shrikant PA, Kim HL. Temsirolimus, an mTOR inhibitor, enhances anti-tumour effects of heat shock protein cancer vaccines. Br J Cancer. 2011; 104: 643-652.

112. Altman JK, Sassano A, Platanias LC. Targeting mTOR for the treatment of AML. New agents and new directions. Oncotarget. 2011; 2: 510-517.

113. Cornu M, Albert V, Hall MN. mTOR in aging, metabolism, and cancer. Curr Opin Genet Dev. 2012.

114. Major P. Potential of mTOR inhibitors for the treatment of subependymal giant cell astrocytomas in tuberous sclerosis complex. Aging (Albany NY). 2011; 3: 189-191.

115. Armstrong AJ, George DJ, Halabi S. Serum lactate dehydrogenase predicts for overall survival benefit in patients with metastatic renal cell carcinoma treated with inhibition of mammalian target of rapamycin. J Clin Oncol. 2012; 30: 3402-3407.

116. van Heemst D, Beekman M, Mooijaart SP, Heijmans BT, Brandt BW, Zwaan BJ, Slagboom PE, Westendorp RG. Reduced insulin/IGF-1 signalling and human longevity. Aging Cell. 2005; 4: 79-85.

117. Bartke A. Long-lived Klotho mice: new insights into the roles of IGF-1 and insulin in aging. Trends Endocrinol Metab. 2006; 17: 33-35.

118. de Magalhaes JP. A role for Ras signaling in modulating mammalian aging by the GH/IGF1 axis. Aging (Albany NY). 2011; 3: 336-337.

119. McCulloch D, Gems D. Body size, insulin/IGF signaling and aging in the nematode Caenorhabditis elegans. Exp Gerontol. 2003; 38: 129-136.

120. Partridge L, Alic N, Bjedov I, Piper MD. Ageing in Drosophila: the role of the insulin/Igf and TOR signalling network. Exp Gerontol. 2011; 46: 376-381.

121. Chateau MT, Araiz C, Descamps S, Galas S. Klotho interferes with a novel FGF-signalling pathway and insulin/ Igf-like signalling to improve longevity and stress resistance in Caenorhabditis elegans. Aging (Albany NY). 2010; 2: 567-581.

122. Liu B, Fan Z, Edgerton SM, Yang X, Lind SE, Thor AD. Potent anti-proliferative effects of metformin on trastuzumab-resistant breast cancer cells via inhibition of erbB2/IGF-1 receptor interactions. Cell Cycle. 2011; 10: 2959-2966.

123. Reidy-Lagunes DL, Vakiani E, Segal MF, Hollywood EM, Tang LH, Solit DB, Pietanza MC, Capanu M, Saltz LB. A phase 2 study of the insulin-like growth factor-1 receptor inhibitor MK-0646 in patients with metastatic, welldifferentiated neuroendocrine tumors. Cancer. 2012; 118: 4795-4800.

124. Hart LS, Dolloff NG, Dicker DT, Koumenis C, Christensen JG, Grimberg A, El-Deiry WS. Human colon cancer stem cells are enriched by insulin-like growth factor-1 and are sensitive to figitumumab. Cell Cycle. 2011; 10: 23312338.

125. Shaw LM. The insulin receptor substrate (IRS) proteins: at the intersection of metabolism and cancer. Cell Cycle. 2011; 10: 1750-1756.

126. DeAngelis T, Wu K, Pestell R, Baserga R. The type 1 insulin-like growth factor receptor and resistance to DACH1. Cell Cycle. 2011; 10: 1956-1959.

127. Fernandez MC, Venara M, Nowicki S, Chemes HE, Barontini M, Pennisi PA. Igf-I regulates pheochromocytoma cell proliferation and survival in vitro and in vivo. Endocrinology. 2012; 153: 3724-3734.

128. Shao M, Hollar S, Chambliss D, Schmitt J, Emerson R, Chelladurai B, Perkins S, Ivan M, Matei D. Targeting the insulin growth factor and the vascular endothelial growth factor pathways in ovarian cancer. Mol Cancer Ther. 2012; 11: $1576-1586$.

129. Ucar DA, Kurenova E, Garrett TJ, Cance WG, Nyberg C, Cox A, Massoll N, Ostrov DA, Lawrence N, Sebti SM, Zajac-Kaye M, Hochwald SN. Disruption of the protein interaction between FAK and IGF-1R inhibits melanoma tumor growth. Cell Cycle. 2012; 11: 3250-3259.

130. Serrano M, Lim AW, McCurrach ME, Beach D, Lowe SW. Oncogenic ras provokes premature cell senescence associated with accumulation of p53 and p16INK1A. Cell. 1997; 88: 593-602.

131. Serrano M, Blasco MA. Putting the stress on senescence. Curr Opin Cell Biol. 2001; 13: 748-753.

132. Zhu JY, Woods D, McMahon M, Bishop JM. Senescence of human fibroblasts induced by oncogenic Raf. Genes Dev. 1998; 12: 2997-3007.

133. Chen Z, Trotman LC, Shaffer D, Lin HK, Dotan ZA, Niki M, Koutcher JA, Scher HI, Ludwig T, Gerald W, CordonCardo C, Pandolfi PP. Crucial role of p53-dependent cellular senescence in suppression of Pten-deficient tumorigenesis. Nature. 2005; 436: 725-730.

134. Ferbeyre G, de Stanchina E, Lin AW, Querido E, McCurrach ME, Hannon GJ, Lowe SW. Oncogenic ras and p53 cooperate to induce cellular senescence. Mol Cell Biol. 2002; 22: 3497-3508.

135. Bansal R, Nikiforov MA. Pathways of oncogene-induced senescence in human melanocytic cells. Cell Cycle. 2010; 9: 2782-2788.

136. Mannava S, Grachtchouk V, Wheeler LJ, Im M, Zhuang D, Slavina EG, Mathews CK, Shewach DS, Nikiforov MA. Direct role of nucleotide metabolism in C-MYC-dependent proliferation of melanoma cells. Cell Cycle. 2008; 7: 23922400. 
137. Lin AW, Barradas M, Stone JC, van Aelst L, Serrano M, Lowe SW. Premature senescence involving p53 and p16 is activated in response to constitutive MEK/MAPK mitogenic signaling. Genes Dev. 1998; 12: 3008-3019.

138. Kosar M, Bartkova J, Hubackova S, Hodny Z, Lukas J, Bartek J. Senescence-associated heterochromatin foci are dispensable for cellular senescence, occur in a cell typeand insult-dependent manner and follow expression of p16(ink4a). Cell Cycle. 2011; 10: 457-468.

139. Lock R, Debnath J. Ras, autophagy and glycolysis. Cell Cycle. 2011; 10: 1516-1517.

140. Borras C, Monleon D, Lopez-Grueso R, Gambini J, Orlando L, Pallardo FV, Santos E, Vina J, Font de Mora J. RasGrf1 deficiency delays aging in mice. Aging (Albany NY). 2011; 3: 262-276.

141. Davies KJ, Forman HJ. RasGrfl and aging. Aging (Albany NY). 2011; 3: 455.

142. Mirisola MG, Longo VD. Conserved role of Ras-GEFs in promoting aging: from yeast to mice. Aging (Albany NY). 2011; 3: 340-343.

143. Ratajczak MZ, Kucia M, Liu R, Shin DM, Bryndza E, Masternak MM, Tarnowski M, Ratajczak J, Bartke A. RasGrf1: genomic imprinting, VSELs, and aging. Aging (Albany NY). 2011; 3: 692-697.

144. Chappell WH, Steelman LS, Long JM, Kempf RC, Abrams SL, Franklin RA, Basecke J, Stivala F, Donia M, Fagone P, Malaponte G, Mazzarino MC, Nicoletti F, Libra M, Maksimovic-Ivanic D, Mijatovic S et al. Ras/Raf/MEK/ ERK and PI3K/PTEN/Akt/mTOR inhibitors: rationale and importance to inhibiting these pathways in human health. Oncotarget. 2011; 2: 135-164.

145. Qiu W, Sahin F, Iacobuzio-Donahue CA, GarciaCarracedo D, Wang WM, Kuo CY, Chen D, Arking DE, Lowy AM, Hruban RH, Remotti HE, Su GH. Disruption of p16 and activation of Kras in pancreas increase ductal adenocarcinoma formation and metastasis in vivo. Oncotarget. 2011; 2: 862-873.

146. Burger JA, Hoellenriegel J. Phosphoinositide 3'-kinase delta: turning off BCR signaling in Chronic Lymphocytic Leukemia. Oncotarget. 2011; 2: 737-738.

147. Sokolosky ML, Stadelman KM, Chappell WH, Abrams SL, Martelli AM, Stivala F, Libra M, Nicoletti F, Drobot LB, Franklin RA, Steelman LS, McCubrey JA. Involvement of Akt-1 and mTOR in sensitivity of breast cancer to targeted therapy. Oncotarget. 2011; 2: 538-550.

148. Busaidy NL, Farooki A, Dowlati A, Perentesis JP, Dancey JE, Doyle LA, Brell JM, Siu LL. Management of metabolic effects associated with anticancer agents targeting the PI3KAkt-mTOR pathway. J Clin Oncol. 2012; 30: 2919-2928.

149. Mendiburu-Elicabe M, Yin D, Hadaczek P, Zhai Y, Forsayeth J, Bankiewicz KS. Systemic rapamycin alone may not be a treatment option for malignant glioma: evidence from an in vivo study. J Neurooncol. 2012; 108: 53-58.
150. Hart JR, Vogt PK. Phosphorylation of AKT: a mutational analysis. Oncotarget. 2011; 2: 467-476.

151. Fraser M, Harding SM, Zhao H, Coackley C, Durocher D, Bristow RG. MRE11 promotes AKT phosphorylation in direct response to DNA double-strand breaks. Cell Cycle. 2011; 10: 2218-2232.

152. Chow HY, Jubb AM, Koch JN, Jaffer ZM, Stepanova D, Campbell DA, Duron SG, O'Farrell M, Cai KQ, KleinSzanto AJ, Gutkind JS, Hoeflich KP, Chernoff J. p21Activated kinase 1 is required for efficient tumor formation and progression in a Ras-mediated skin cancer model. Cancer Res. 2012; 72: 5966-5975.

153. Ramaswamy B, Lu Y, Teng KY, Nuovo G, Li X, Shapiro $\mathrm{CL}$, Majumder S. Hedgehog signaling is a novel therapeutic target in tamoxifen-resistant breast cancer aberrantly activated by PI3K/AKT pathway. Cancer Res. 2012; 72 : 5048-5059.

154. Steelman LS, Navolanic P, Chappell WH, Abrams SL, Wong EW, Martelli AM, Cocco L, Stivala F, Libra M, Nicoletti F, Drobot LB, Franklin RA, McCubrey JA. Involvement of Akt and mTOR in chemotherapeutic- and hormonal-based drug resistance and response to radiation in breast cancer cells. Cell Cycle. 2011; 10: 3003-3015.

155. Corcoran RB, Settleman J, Engelman JA. Potential therapeutic strategies to overcome acquired resistance to BRAF or MEK inhibitors in BRAF mutant cancers. Oncotarget. 2011; 2: 336-346.

156. Beausejour CM, Krtolica A, Galimi F, Narita M, Lowe SW, Yaswen P, Campisi J. Reversal of human cellular senescence: roles of the p53 and p16 pathways. EMBO J. 2003; 22: 4212-4222.

157. Campisi J. Senescent cells, tumor suppression, and organismal aging: good citizens, bad neighbors. Cell. 2005; 120: 513-522.

158. Itahana K, Dimri G, Campisi J. Regulation of cellular senescence by p53. Eur J Biochem. 2001; 268: 2784-2791.

159. Vigneron A, Vousden KH. p53, ROS and senescence in the control of aging. Aging (Albany NY). 2010; 2: 471-474.

160. Mallette FA, Calabrese V, Ilangumaran S, Ferbeyre G. SOCS1, a novel interaction partner of p53 controlling oncogene-induced senescence. Aging (Albany NY). 2010; 2: 445-452.

161. Pinho AV, Rooman I, Real FX. p53-dependent regulation of growth, epithelial-mesenchymal transition and stemness in normal pancreatic epithelial cells. Cell Cycle. 2011; 10: 1312-1321.

162. Korotchkina LG, Leontieva OV, Bukreeva EI, Demidenko ZN, Gudkov AV, Blagosklonny MV. The choice between p53-induced senescence and quiescence is determined in part by the mTOR pathway. Aging (Albany NY). 2010; 2: 344-352.

163. Levine AJ, Feng Z, Mak TW, You H, Jin S. Coordination and communication between the p53 and IGF-1-AKT-TOR signal transduction pathways. Genes Dev. 2006; 20: 267- 
275.

164. Demidenko ZN, Korotchkina LG, Gudkov AV, Blagosklonny MV. Paradoxical suppression of cellular senescence by p53. Proc Natl Acad Sci U S A. 2010; 107: 9660-9664.

165. Leontieva O, Gudkov A, Blagosklonny M. Weak p53 permits senescence during cell cycle arrest. Cell Cycle. 2010; 9: 4323-4327.

166. Lane DP, Verma C, Fang CC. The p53 inducing drug dosage may determine quiescence or senescence. Aging (Albany NY). 2010; 2: 748.

167. Galluzzi L, Kepp O, Kroemer G. TP53 and MTOR crosstalk to regulate cellular senescence. Aging (Albany NY). 2010; 2: $535-537$.

168. Darzynkiewicz Z. Another "Janus paradox" of p53: induction of cell senescence versus quiescence. Aging (Albany NY). 2010; 2: 329-330.

169. Yin MJ. Linking Nek6 to p53-induced senescence. Cell Cycle. 2011; 10: 18 .

170. Dulic V. Be quiet and you'll keep young: does mTOR underlie p53 action in protecting against senescence by favoring quiescence? Aging (Albany NY). 2011; 3: 3-4.

171. Maki CG. Decision-making by p53 and mTOR. Aging (Albany NY). 2010; 2: 324-326.

172. Tyner SD, Venkatachalam S, Choi J, Jones S, Ghebranious N, Igelmann H, Lu X, Soron G, Cooper B, Brayton C, Hee Park S, Thompson T, Karsenty G, Bradley A, Donehower LA. p53 mutant mice that display early ageing-associated phenotypes. Nature. 2002; 415: 45-53.

173. Maier B, Gluba W, Bernier B, Turner T, Mohammad K, Guise T, Sutherland A, Thorner M, Scrable H. Modulation of mammalian life span by the short isoform of p53. Genes Dev. 2004; 18: 306-319.

174. Capri M, Salvioli S, Sevini F, Valensin S, Celani L, Monti D, Pawelec G, De Benedictis G, Gonos ES, Franceschi C. The genetics of human longevity. Ann N Y Acad Sci. 2006; 1067: 252-263.

175. Pinkston JM, Garigan D, Hansen M, Kenyon C. Mutations that increase the life span of C. elegans inhibit tumor growth. Science. 2006; 313: 971-975.

176. Poyurovsky MV, Prives C. P53 and aging: A fresh look at an old paradigm. Aging (Albany NY). 2010; 2: 380-382.

177. Matheu A, Maraver A, Klatt P, Flores I, Garcia-Cao I, Borras C, Flores JM, Vi-a J, Blasco MA, Serrano M. Delayed ageing through damage protection by the Arf/p53 pathway. Nature. 2007; 448: 375-379.

178. Bojesen SE, Nordestgaard BG. The common germline Arg72Pro polymorphism of p53 and increased longevity in humans. Cell Cycle. 2008; 7.

179. de Keizer PL, Laberge RM, Campisi J. p53: Pro-aging or pro-longevity? Aging (Albany NY). 2010; 2: 377-379.

180. Bauer J, Antosh M, Chang C, Schorl C, Kolli S, Neretti N, Helfand SL. Comparative transcriptional profiling identifies takeout as a gene that regulates life span. Aging (Albany NY). 2010; 2: 298-310.

181. Azmi AS, Banerjee S, Ali S, Wang Z, Bao B, Beck FW, Maitah M, Choi M, Shields TF, Philip PA, Sarkar FH, Mohammad RM. Network modeling of MDM2 inhibitoroxaliplatin combination reveals biological synergy in wtp53 solid tumors. Oncotarget. 2011; 2: 378-392.

182. Kuribayashi K, Finnberg N, Jeffers JR, Zambetti GP, ElDeiry WS. The relative contribution of pro-apoptotic p53target genes in the triggering of apoptosis following DNA damage in vitro and in vivo. Cell Cycle. 2011; 10: 23802389.

183. Bywater MJ, Poortinga G, Sanij E, Hein N, Peck A, Cullinane C, Wall M, Cluse L, Drygin D, Anderes K, Huser N, Proffitt C, Bliesath J, Haddach M, Schwaebe MK, Ryckman DM et al. Inhibition of RNA polymerase I as a therapeutic strategy to promote cancer-specific activation of p53. Cancer Cell. 2012; 22: 51-65.

184. Junttila MR, Karnezis AN, Garcia D, Madriles F, Kortlever RM, Rostker F, Brown Swigart L, Pham DM, Seo Y, Evan GI, Martins CP. Selective activation of p53-mediated tumour suppression in high-grade tumours. Nature. 2010; 468: 567-571.

185. Hupp TR, Hayward RL, Vojtesek B. Strategies for p53 reactivation in human sarcoma. Cancer Cell. 2012; 22: 283-285.

186. Yu X, Vazquez A, Levine AJ, Carpizo DR. Allele-specific p53 mutant reactivation. Cancer Cell. 2012; 21: 614-625.

187. De Raedt T, Walton Z, Yecies JL, Li D, Chen Y, Malone CF, Maertens O, Jeong SM, Bronson RT, Lebleu V, Kalluri R, Normant E, Haigis MC, Manning BD, Wong KK, Macleod KF et al. Exploiting cancer cell vulnerabilities to develop a combination therapy for ras-driven tumors. Cancer Cell. 2011; 20: 400-413.

188. Purvis JE, Karhohs KW, Mock C, Batchelor E, Loewer A, Lahav G. p53 dynamics control cell fate. Science. 2012; 336: 1440-1444.

189. Li L, Wang L, Wang Z, Ho Y, McDonald T, Holyoake TL, Chen W, Bhatia R. Activation of p53 by SIRT1 inhibition enhances elimination of CML leukemia stem cells in combination with imatinib. Cancer Cell. 2012; 21: 266281.

190. Stegh AH, DePinho RA. Beyond effector caspase inhibition: Bcl2L12 neutralizes p53 signaling in glioblastoma. Cell Cycle. 2011; 10: 33-38.

191. Bao W, Chen M, Zhao X, Kumar R, Spinnler C, Thullberg M, Issaeva N, Selivanova G, Stromblad S. PRIMA-1Met/ APR-246 induces wild-type p53-dependent suppression of malignant melanoma tumor growth in $3 \mathrm{D}$ culture and in vivo. Cell Cycle. 2011; 10: 301-307.

192. van Leeuwen IM, Higgins M, Campbell J, Brown CJ, McCarthy AR, Pirrie L, Westwood NJ, Lain S. Mechanismspecific signatures for small-molecule p53 activators. Cell Cycle. 2011; 10: 1590-1598. 
193. Li T, Kon N, Jiang L, Tan M, Ludwig T, Zhao Y, Baer R, $\mathrm{Gu}$ W. Tumor suppression in the absence of p53-mediated cell-cycle arrest, apoptosis, and senescence. Cell. 2012; 149: 1269-1283.

194. Davoli T, de Lange T. Telomere-driven tetraploidization occurs in human cells undergoing crisis and promotes transformation of mouse cells. Cancer Cell. 2012; 21: 765776.

195. Nardinocchi L, Puca R, D’Orazi G. HIF-1alpha antagonizes p53-mediated apoptosis by triggering HIPK2 degradation. Aging (Albany NY). 2011; 3: 33-43.

196. Blagosklonny MV. Hypoxia-inducible factor: Achilles' heel of antiangiogenic cancer therapy (review). Int J Oncol. 2001; 19: 257-262.

197. Demidenko ZN, Blagosklonny MV. The purpose of the HIF-1/PHD feedback loop: to limit mTOR-induced HIF1alpha. Cell Cycle. 2011; 10: 1557-1562.

198. Blagosklonny MV. Antiangiogenic therapy and tumor progression. Cancer Cell. 2004; 5: 13-17.

199. Lee K, Qian DZ, Rey S, Wei H, Liu JO, Semenza GL. Anthracycline chemotherapy inhibits HIF-1 transcriptional activity and tumor-induced mobilization of circulating angiogenic cells. Proc Natl Acad Sci U S A. 2009; 106: 2353-2358.

200. Semenza GL. Evaluation of HIF-1 inhibitors as anticancer agents. Drug Discov Today. 2007; 12: 853-859.

201. Kummar S, Raffeld M, Juwara L, Horneffer Y, Strassberger A, Allen D, Steinberg SM, Rapisarda A, Spencer SD, Figg WD, Chen X, Turkbey IB, Choyke P, Murgo AJ, Doroshow JH, Melillo G. Multihistology, target-driven pilot trial of oral topotecan as an inhibitor of hypoxia-inducible factor1alpha in advanced solid tumors. Clin Cancer Res. 2011; 17: 5123-5131.

202. Onnis B, Rapisarda A, Melillo G. Development of HIF-1 inhibitors for cancer therapy. J Cell Mol Med. 2009; 13: 2780-2786.

203. Blagosklonny MV, Robey R, Bates S, Fojo T. Pretreatment with DNA-damaging agents permits selective killing of checkpoint-deficient cells by microtubule-active drugs. J Clin Invest. 2000; 105: 533-539.

204. Puca R, Nardinocchi L, Porru M, Simon AJ, Rechavi G, Leonetti C, Givol D, D’Orazi G. Restoring p53 active conformation by zinc increases the response of mutant $\mathrm{p} 53$ tumor cells to anticancer drugs. Cell Cycle. 2011; 10: 16791689.

205. Carvajal D, Tovar C, Yang H, Vu BT, Heimbrook DC, Vassilev LT. Activation of p53 by MDM2 antagonists can protect proliferating cells from mitotic inhibitors. Cancer Res. 2005; 65: 1918-1924.

206. Choong ML, Yang H, Lee MA, Lane DP. Specific activation of the $\mathrm{p} 53$ pathway by low dose actinomycin D: a new route to p53 based cyclotherapy. Cell Cycle. 2009; 8: 2810-2818.

207. Apontes P, Leontieva OV, Demidenko ZN, Li F,
Blagosklonny MV. Exploring long-term protection of normal human fibroblasts and epithelial cells from chemotherapy in cell culture. Oncotarget. 2011; 2: 222233.

208. Rao B, van Leeuwen IM, Higgins M, Campbel J, Thompson AM, Lane DP, Lain S. Evaluation of an Actinomycin D/ VX-680 aurora kinase inhibitor combination in p53-based cyclotherapy. Oncotarget. 2010; 1: 639-650.

209. van Leeuwen IM, Lain S. Pharmacological manipulation of the cell cycle and metabolism to protect normal tissues against conventional anticancer drugs. Oncotarget. 2011; 2: 274-276.

210. Paris M, Rouleau M, Puceat M, Aberdam D. Regulation of skin aging and heart development by TAp63. Cell Death Differ. 2012; 19: 186-193.

211. Guo X, Keyes WM, Papazoglu C, Zuber J, Li W, Lowe SW, Vogel H, Mills AA. TAp63 induces senescence and suppresses tumorigenesis in vivo. Nat Cell Biol. 2009; 11: 1451-1457.

212. Flores ER, Lozano G. The p53 family grows old. Genes Dev. 2012; 26: 1997-2000.

213. Aylon Y, Oren M. New plays in the p53 theater. Curr Opin Genet Dev. 21: 86-92.

214. Holder-Espinasse M, Martin-Coignard D, Escande F, Manouvrier-Hanu S. A new mutation in TP63 is associated with age-related pathology. Eur J Hum Genet. 2007; 15: 1115-1120.

215. Marcel V, Dichtel-Danjoy ML, Sagne C, Hafsi H, Ma D, Ortiz-Cuaran S, Olivier M, Hall J, Mollereau B, Hainaut P, Bourdon JC. Biological functions of p53 isoforms through evolution: lessons from animal and cellular models. Cell Death Differ. 2011; 18: 1815-1824.

216. Guglielmino MR, Santonocito M, Vento M, Ragusa M, Barbagallo D, Borzi P, Casciano I, Banelli B, Barbieri O, Astigiano S, Scollo P, Romani M, Purrello M, Di Pietro C. TAp73 is downregulated in oocytes from women of advanced reproductive age. Cell Cycle. 2011; 10: 32533256.

217. Huang Y, Ratovitski EA. Phospho-DeltaNp63alpha/Rpn13dependent regulation of LKB1 degradation modulates autophagy in cancer cells. Aging (Albany NY). 2010; 2: 959-968.

218. Neilsen PM, Noll JE, Suetani RJ, Schulz RB, Al-Ejeh F, Evdokiou A, Lane DP, Callen DF. Mutant p53 uses p63 as a molecular chaperone to alter gene expression and induce a pro-invasive secretome. Oncotarget. 2011; 2: 1203-1217.

219. Melino G. p63 is a suppressor of tumorigenesis and metastasis interacting with mutant p53. Cell Death Differ. 2011; 18: 1487-1499.

220. Graziano V, De Laurenzi V. Role of p63 in cancer development. Biochim Biophys Acta. 2011; 1816: 57-66.

221. Liao JM, Zhou X, Zhang Y, Lu H. MiR-1246: a new link of the p53 family with cancer and Down syndrome. Cell Cycle. 2012; 11: 2624-2630. 
222. Ory B, Ellisen LW. A microRNA-dependent circuit controlling p63/p73 homeostasis: p53 family cross-talk meets therapeutic opportunity. Oncotarget. 2011; 2: 259264.

223. Zawacka-Pankau J, Kostecka A, Sznarkowska A, Hedstrom E, Kawiak A. p73 tumor suppressor protein: a close relative of $\mathrm{p} 53$ not only in structure but also in anti-cancer approach? Cell Cycle. 2010; 9: 720-728.

224. Soleimani R, Heytens E, Darzynkiewicz Z, Oktay K. Mechanisms of chemotherapy-induced human ovarian aging: double strand DNA breaks and microvascular compromise. Aging (Albany NY). 2011; 3: 782-793.

225. Muppani N, Nyman U, Joseph B. TAp73alpha protects small cell lung carcinoma cells from caspase-2 induced mitochondrial mediated apoptotic cell death. Oncotarget. 2011; 2: 1145-1154.

226. D'Agostino L, Giordano A. A novel dual signaling axis for NSP 5a3a induced apoptosis in head and neck carcinoma. Oncotarget. 2011; 2: 1055-1074.

227. Bisso A, Collavin L, Del Sal G. p73 as a pharmaceutical target for cancer therapy. Curr Pharm Des. 2011; 17: 578590.

228. Marcel V, Petit I, Murray-Zmijewski F, Goullet de Rugy T, Fernandes K, Meuray V, Diot A, Lane DP, Aberdam D, Bourdon JC. Diverse p63 and p73 isoforms regulate Delta133p53 expression through modulation of the internal TP53 promoter activity. Cell Death Differ. 2012; 19: 816826.

229. Muller M, Schleithoff ES, Stremmel W, Melino G, Krammer PH, Schilling T. One, two, three--p53, p63, p73 and chemosensitivity. Drug Resist Updat. 2006; 9: 288306.

230. Vilgelm A, El-Rifai W, Zaika A. Therapeutic prospects for p73 and p63: rising from the shadow of p53. Drug Resist Updat. 2008; 11: 152-163. 